\title{
Toxic constituents of plant foodstuffs
}

\author{
By Irvin E. Liener, Department of Biochemistry, University of Minnesota, St. Paul, \\ Minnesota, $U S A$
}

Unlike chemical additives which are deliberately introduced into foods, naturallyoccurring toxic substances pose a special problem since their elimination cannot be effected by legislative action. This paper deals with those toxic or antinutritional factors that are found in plants that have present or potential value as sources of protein for human diets or animal feeds. Particular emphasis is given to the means whereby these substances may be eliminated or inactivated so as to produce a dietary source of protein that is no longer a hazard to the animal or human organism. Further details and references are given elsewhere (Liener, 1966).

Proteins that have the ability to inhibit the activity of trypsin, one of the important enzymes involved in the digestion of proteins in man and animals, are widely distributed among the legumes. The soya-bean trypsin inhibitor is undoubtedly responsible, at least in part, for the poor nutritive value of unheated soya beans and the beneficial effect of heat treatment. 'The mechanism whereby the trypsin inhibitor exerts its growth-inhibiting effect is not clear, although it appears to be related to the pancreatic hypertrophy which is associated with its presence in the diet.

Proteins that have the unique property of causing the agglutination of red blood cells are also present in most legumes. With the isolation of these so-called phytohaemagglutinins it has been possible to demonstrate that these proteins are responsible to a large extent for the severe growth retardation and eventual death produced in rats fed raw beans (Phaseolus vulgaris). The site of action of the phytohaemagglutinins is believed to be the intestinal mucosa whose absorptive capacity is impaired as a consequence of the binding of the mucosal cells with the phytohaemagglutinin.

Human lathyrism is generally associated with the consumption of Lathyrus satious. An amino acid, $\beta$ - $N$-oxalyl-L- $\alpha, \beta$-diaminopropionic acid, has been isolated from the seeds of this plant and its injection into chicks produces toxic neurological effects, evidence which suggests that this compound may be the principle responsible for human lathyrism.

Certain cruciferous oilseeds such as rapeseed and mustard seed are known to contain thioglycosides that, upon enzymatic hydrolysis, release goitrogenic substances such as allyl isothiocyanate and L-5-vinyl-2-oxazolidinethione. Since the release of these goitrogenic agents is catalysed by enzymes already present in the meal, destruction of these enzymes by heat treatment serves to reduce the goitrogenicity of rapeseed and mustard-seed meals. Cyanide-containing glycosides are found in lima beans, sorghum, cassava, linseed meal, and, to a lesser extent, in certain legumes. Detoxification of these plants may be generally achieved by thermal inactivation of the enzymes that effect the release of cyanide from these glycosides. 
Favism is a disease characterized by haemolytic anaemia that affects certain individuals following the ingestion of the broad or field bean, Vicia faba. In spite of rather extensive studies that have been made regarding the clinical and biochemical manifestations of favism, the causative principle of favism has not been identified with any degree of certainty. Recent evidence would suggest, however, that perhaps vicine, a nucleoside composed of glucose and 2,5-diamino-4,5-diketopyrimidine, may be responsible for favism, at least in persons genetically susceptible to this disease.

There exists a fairly large category of natural substances that interfere with the utilization of certain minerals and vitamins. As examples, isolated soya-bean protein has been shown to interfere with the availability of such minerals as zinc, manganese, copper and iron as well as vitamin D; raw kidney beans contain a factor that increases the vitamin $\mathrm{E}$ requirements of the chick; and linseed meal contains an antagonist of pyridoxine. Only the latter has been identified and has been shown to be I-amino-D-proline.

The significance of naturally-occurring toxicants in human nutrition is still largely unknown, and they may not in fact pose much of a problem as long as man is able to select a varied diet. But there is the possibility that the prolonged consumption of any one foodstuff may bring to the surface toxic effects that have not heretofore been apparent. It is this sort of occurrence that may be expected to become more commonplace as the shortage of protein becomes more acute, and certain segments of the population are forced to become less discriminating in their choice of lifesustaining foods. By selecting those strains and varieties of plants that are genetically deficient in components of possible toxicity to man, the co-operative efforts of the nutritionist and plant breeder can do much to forestall this problem.

REFERENCE

Liener, I. E. (1966). Adv. Chem. Ser. 57, I78.

\section{Factors affecting the limitation of the cultivation of grain legumes in tropical territories}

By W. R. Stanton, Tropical Products Institute, Gray's Inn Road, London, WCI

The apparently simple question 'Why is a crop not grown in an agricultural situation which appears to be ecologically suitable?' is one of those on many tropical food crops that still require an answer. The problem is quite distinct from that with cash crops in that, for the latter, questions of world trade, monetary economics, scale of operation and transport also arise.

For the food crops the search for an answer taxes the skill of the agronomist to the full; here I use the term 'agronomist' in its broadest sense, meaning a student 